\title{
FENOMENA PEMAKAIAN PRONOMINA (DHOMIR) ANTUM SEBAGAI REPRESENTASI PRINSIP KESANTUNAN DI PONDOK MODERN AN-NAJAH CINDAI ALUS PUTRI
}

\author{
Restuwati Azhar* \\ Email : azharrezha.012@gmail.com \\ Magister Linguistik, Fakultas Ilmu Budaya, Universitas Gadjah Mada, Yogyakarta, \\ Indonesia
}

Article history

Received

Revised

Accepted

Keywords

Pronoun

Dhomir

Representation

The principle of politeness
This study was conducted in order to 1) describe the use of pronoun 'antum' by students in daily basis interactions, and 2) describe the relationship between the use of the pronoun 'antum' and the principle of politeness. The data in this study were obtained through the method of participants observations and the distribution of questionnaires containing questions with open answers pattern. The results of the analysis have indicated that the pronoun 'antum' is used by students as a pronoun that refers to the second person for the plural male, for the elder person, and for the person who is respected. In addition, the use of the pronoun 'antum' is a way of showing respect for older person or respected speech partners, and is considered as a form of 'costumized' politeness.

This is an open access article under the CC-BY-SA license.

\section{Artikel histori}

Dikirim

Diperbaiki

Diterima

Kata kunci

Pronominal

Dhomir

Representasi

Prinsip kesantunan
Penelitian ini bertujuan untuk 1) mendeskripsikan bagaimana pronomina antum digunakan oleh santriwati dalam interaksi sehari-hari, dan 2) mendeskripsikan bagaimana hubungan antara penggunaan pronomina antum dan prinsip kesantunan. Data dalam penelitian ini diperoleh melalui metode observasi partisipan dan juga penyebaran angket berisi pertanyaan dengan pola jawaban terbuka. Hasil penelitian ini menunjukkan bahwa pronomina antum dalam keseharian santriwati digunakan sebagai kata ganti yang mengacu pada kata ganti orang kedua laki-laki jamak, kata ganti sapaan terhadap orang yang lebih tua, dan kata ganti sapaan terhadap orang yang dihormati atau disegani.Selain itu, penggunaan pronomina antum adalah salah satu cara menunjukkan rasa hormat kepada mitra tutur yang lebih tua atau disegani, dan dianggap sebagai adat kebiasaan terkait kesopanan. 


\section{PENDAHULUAN}

Menurut Meyer (2009), terdapat sekitar 6.000-7.000 bahasa di dunia yang secara aktif digunakan sebagai sarana untuk berkomunikasi. Salah satu di antara bahasa yang aktif tersebut adalah bahasa Arab, yang bahkan sudah menempati posisi sebagai bahasa internasional. Bahasa Arab sudah diakui menjadi bahasa internasional semenjak dikukuhkan menjadi salah satu bahasa resmi Persatuan Bangsa-Bangsa (PBB) pada 18 Desember 1973 (Sartono, n.d., dalam Badan Pengembangan dan Pembinaan Bahasa). Hal ini didukung dengan fakta bahwa bahasa Arab sudah dipakai oleh orang di berbagai belahan dunia sebagai sarana komunikasi, bisnis, pendidikan, dan ilmu pengetahuan bahkan juga media diplomasi. Di Indonesia sendiri, bahasa Arab adalah bahasa yang dipelajari sebagai bahasa asing di berbagai jenjang pendidikan; dari sekolah dasar hingga perguruan tinggi.

Pondok Modern An-Najah Cindai Alus Putri adalah salah satu pondok pesantren di kabupaten Banjar, provinsi Kalimantan Selatan yang menerapkan pemakaian bahasa internasional sebagai alat komunikasi bagi para santriwati dalam interaksi sehari-hari. Bahasa internasional yang digunakan adalah bahasa Arab dan bahasa Inggris. Dalam penerapannya, kedua bahasa tersebut berganti setiap pekannya dan wajib dipakai oleh santriwati yang mukim di asrama. Pada kurikulum pembelajaran, bahasa Arab memegang peranan yang lebih dominan dibanding bahasa Inggris sebagai bahasa pengantar dalam kegiatan belajar mengajar. Hal ini dibuktikan dengan lebih banyaknya mata pelajaran dengan referensi yang tertulis dalam bahasa Arab dibanding bahasa Inggris.

Bahasa Arab yang dipelajari oleh santriwati di Pondok Modern An-Najah Cindai Alus Putri adalah bahasa Arab standar yang mengikuti kaidah bahasa dalam Al-Quran. Namun demikian, pada penggunaannya sebagai alat berkomunikasi sehari-hari, bahasa Arab yang dipakai para santriwati mengalami sedikit pergeseran. Penggunaan pronomina antum yang memiliki arti 'kalian laki-laki' adalah hal yang lazim ditemukan ketika santriwati menyapa orang yang lebih tua atau dihormati seperti pada saat berinteraksi dengan guru atau kakak kelas.

Fenomena penggunaan pronomina antum menjadi fokus dalam penelitian kali ini. Adapun rumusan masalah dalam penelitian ini adalah: 1) Bagaimana penggunaan pronomina antum dalam interaksi sehari-hari santriwati di Pondok Modern An-Najah Cindai Alus Putri? dan 2) Bagaimana hubungan antara penggunaan pronomina antum dan prinsip kesantunan? Rumusan masalah tersebut diajukan dengan tujuan untuk 1) mendeskripsikan bagaimana pronomina antum digunakan oleh santriwati dalam interaksi sehari-hari, dan 2) mendeskripsikan bagaimana hubungan antara penggunaan pronomina antum dan prinsip kesantunan.

Menurut KBBI daring (kbbi.kemdikbud.go.id) pronomina adalah kata yang dipakai untuk mengganti orang atau benda. Dengan kata lain, pronomina merupakan kata ganti yang mengacu pada nomina yang dapat berfungsi menjadi subjek atau objek dalam sebuah ujaran/klausa. Pada bahasa Arab, pronomina disebut dengan ismu dhomir yang mengacu pada kata benda yang tersembunyi dan diperuntukkan bagi orang pertama, orang kedua, dan orang ketiga (Al-Atsary, 2007: 21). Menurut Al Jarim dan Amin (2005: 79) ismu dhomir adalah kata 


MIMESIS
VOL. 2. No. 1, Januari 2021
Universitas
Ahmad Dahlan

benda konkret yang ditandai dengan kata ganti orang pertama, atau kata ganti orang kedua, atau kata ganti orang ketiga.

Terdapat 14 dhomir dalam bahasa Arab (Razin \& Razin, 2015: 30; Al Jarim \& Amin, 2005: 82) yaitu huwa 'dia laki-laki', humaa 'mereka berdua laki-laki', hum 'mereka laki-laki', hiya 'dia perempuan', humaa 'mereka berdua perempuan', hunna 'mereka perempuan', anta 'kamu laki-laki', antumaa 'kalian berdua laki-laki', antum 'kalian laki-laki', anti 'kamu perempuan', antumaa 'kalian berdua perempuan', antunna 'kalian perempuan', anaa 'saya', dan nahnu 'kami'. Beberapa dari pronomina tersebut akan berubah bentuk ketika menjadi objek dalam suatu ujaran atau klausa, begitu pula ketika menjadi kata ganti kepemilikan.

Muslich (2007) menyatakan bahwa dalam interaksi sehari-hari, kesantunan dapat dilihat dari beberapa aspek. Pertama, kesantunan memperlihatkan sikap yang mengandung nilai sopan santun atau etiket dalam pergaulan sehari-hari. Kedua, kesantunan bersifat kontekstual, artinya dia bisa berlaku pada masyarakat tertentu tapi belum tentu berlaku di masyarakat yang lain. Contohnya adalah ketika bertemu dengan teman akrab, bisa saja pilihan kata yang digunakan agak kasar. Tetapi ketika bertemu dengan orang yang baru dikenal, kata-kata kasar akan menjadi hal yang melanggar kesantunan. Ketiga, kesantunan selalu memiliki hubungan dua sisi, seperti antara anak dan orang tua, orang yang lebih tua dan orang yang lebih muda, pria dan wanita, dan lain-lain. Keempat, kesantunan dapat dilihat dari cara berpakaian, cara bertindak, dan cara bertutur (berbahasa). Rahadini (2020: 25) menyimpulkan bahwa kesantunan berbahasa memiliki tujuan utama untuk menghindari kemungkinan timbulnya konflik yang dihasilkan oleh penggunaan bahasa.

Dalam berinteraksi dengan orang lain, Wardhaugh \& Fuller (2015: 256) menyatakan bahwa semua orang memiliki kewajiban untuk melindungi 'muka' atau citra diri milik mereka sendiri dan juga milik orang lain. Brown dan Levinson (1987, dalam Wardhaugh \& Fuller, 2015) mendefinisikan 'muka' sebagai citra diri di hadapan publik yang ingin ditampilkan oleh semua orang. Brown dan Levinson (1987, dalam Rusbiyantoro, 2014) menyatakan bahwa dalam masyarakat terdapat tiga skala yang dipakai untuk mengukur kesantunan. Ketiga skala tersebut ialah jarak sosial antara penutur dan mitra tuturnya, hubungan kekuasaan yang ada di antara penutur dan mitra tutur, dan tingkat relativitas kedudukan tuturan dalam suatu situasi dibanding dengan situasi yang lain.

Untuk menjelaskan perilaku kesantunan berbahasa, Leech (2014: 35) mengemukakan 6 maksim yaitu (1) maksim kebijaksanaan: meminimalkan upaya untuk orang lain, dan memaksimalkan manfaat untuk orang lain; (2) maksim kemurahan hati: meminimalkan keuntungan untuk diri sendiri dan memaksimalkan upaya untuk diri sendiri; (3) maksim penerimaan: meminimalkan rasa tidak hormat orang lain, dan memaksimalkan pujian pada orang lain; (4) maksim kerendahan hati: meminimalkan pujian untuk diri sendiri, dan memaksimalkan kerendahan hati pada diri sendiri; (5) maksim kesepakatan: meminimalkan ketidaksepakatan antara diri sendiri dan orang lain, dan memaksimalkan kesepakatan antara diri sendiri dan orang lain; dan (6) maksim kesimpatisan: memaksimalkan rasa simpati terhadap orang lain. 


MIMESIS
UND. 2. No. 1, Januari 2021
Universitas
Ahmad Dahlan

\section{METODE}

Penelitian ini menggunakan metode deskriptif dengan bentuk penelitian kualitatif. Data pada penelitian ini diambil dengan menerapkan metode observasi partisipan, di mana peneliti turut andil sebagai instrument penelitian guna menemukan data terkait penggunaan pronomina antum. Kemudian, peneliti juga menyebarkan angket dengan pola jawaban terbuka untuk mengkaji bagaimana hubungan antara penggunaan pronomina antum dan prinsip kesantunan. Informan dari penelitian ini adalah 10 orang alumni dari Pondok Modern An-Najah Cindai Alus Putri. Terdapat 6 orang informan yang pernah menjadi pengajar di Pondok Modern AnNajah Cindai Alus Putri, 2 orang di antaranya hingga kini masih berstatus pengajar.

\section{PEMBAHASAN}

\section{Penggunaan Pronomina (Dhomir) Antum dalam Interaksi Keseharian Santriwati}

Penggunaan pronomina antum yang secara leksikal memiliki makna 'kalian laki-laki' sudah mengalami perluasan makna ketika digunakan oleh santriwati di Pondok Modern AnNajah Cindai Alus Putri. Menurut Chaer (2014: 310 - 311) makna sebuah kata secara diakronis berpotensi untuk berubah dengan dipengaruhi oleh beberapa faktor, salah satunya adalah perkembangan sosial budaya. Sikap sosial dan budaya masyarakat yang selalu berubah dan berkembang menyebabkan perubahan makna pada kata yang dipilih dan digunakan. Adapun penggunaan pronomina antum oleh santriwati Pondok Modern An-Najah Cindai Alus Putri akan dijelaskan secara lengkap di bawah ini.

\section{- Dhomir Antum sebagai kata ganti yang mengacu pada 'kalian laki-laki'}

Menurut kaidah tata bahasa, penggunaan dhomir antum mengacu pada 'kalian laki-laki' atau yang disebut dengan mukhotobun 'orang kedua jamak' (Al-Atsary, 2007; Razin dan Razin, 2015; Al Jarim \& Amin, 2005). Pada santriwati Pondok Modern An-Najah penggunaan umum ini berlaku sesuai dengan kaidah tata bahasa yang ada yaitu dipakai untuk menyapa orang kedua laki-laki yang berjumlah lebih dari 2 orang. Dalam fungsinya pun, pronomina antum ini berubah sesuai dengan kaidah perubahannya ketika dia menjadi objek dan juga ketika menjadi kata ganti kepemilikan.

\section{- Dhomir Antum sebagai kata ganti yang dipakai untuk menyapa orang yang lebih tua}

Dalam penggunaanya ketika berinteraksi sehari-hari, penggunaan pronomina antum umumnya dipakai sebagai kata ganti sapaan terhadap orang yang lebih senior secara usia. Santriwati cenderung menggunakan pronomina antum untuk menyapa kakak kelas di lingkungan sekolah dan asrama. Berikut contoh penggunaan pronomina antum untuk menyapa orang yang lebih tua.

(1) Hal akaltum, ya Ukhti Nisa? 'Apakah kamu sudah makan, Kak Nisa?

(2) Ukhti Jannah, bil amsi roaytukum fiy Q-Mall. 'Kak Jannah, kemarin saya melihat antum di Q-Mall.

Pada sampel (1) pronomina antum dipakai untuk mengganti pronomina anti 'kamu perempuan' pada sebuah ujaran atau kalimat interogatif. Pronomina antum sendiri datang 


MIMESIS
VOL. 2. No. 1, Januari 2021
Universitas
Ahmad Dahlan

setelah kata kerja akala yang berarti 'makan' dalam bentuk lampau, sehingga pronomina antum berubah bentuk dan bergabung dengan kata kerja akala membentuk kata akaltum. Kemudian, pada sampel (2) didapati bahwa penutur menyatakan sebuah kalimat deklaratif yang bertujuan memberikan informasi secara ringkas. Pronomina antum pada kalimat ini berfungsi sebagai objek dan juga dating setelah kata kerja yang berfungsi sebagai predikat dari subjek anaa 'saya'.

\section{- Dhomir Antum sebagai kata ganti yang dipakai untuk menyapa orang yang dihormati}

Selain digunakan untuk sebagai kata ganti orang kedua laki-laki jamak dan sebagai kata ganti yang dipakai untuk menyapa orang yang lebih tua, pronomina antum juga dipakai ketika penutur menyapa orang yang dihormati atau disegani. Data yang dikaji menunjukkan bahwa pronomina antum lazim digunakan oleh para santriwati pada saat melakukan interaksi dengan ustaz atau ustazah pengajar mereka, baik itu di lingkungan sekolah mau pun di lingkungan asrama. Berikut contoh penggunaan pronomina antum pada interaksi santri dan ustaz/ustazah pengajar mereka.

(3) Hal yumkin an as'alakum syai'an, ya ustadzah? 'Bolehkah saya bertanya, ustazah?'

Pada sampel (3) pronomina antum berfungsi sebagai objek dan kata ganti yang orang kedua. Meski seharusnya kata ganti yang dipakai adalah dhomir anti dikarenakan mitra tutur yang disapa adalah orang kedua perempuan tunggal, penutur tetap memakai pronomina antum sebagai kata ganti atas alasan kesopanan.

\section{Hubungan Penggunaan Pronomina Antum dan Prinsip Kesantunan}

Pada dasarnya penggunaan pronomina (dhomir) antum sudah sejak lama dipakai oleh santriwati Pondok Modern An-Najah Cindai Alus Putri. dari data yang dikaji, ditemukan bahwa penggunaan pronomina antum dianggap sebagai adat kebiasaan terkait kesopanan yang berlaku di Pondok Modern An-Najah. Hal ini selaras dengan pernyataan Muslich (2007) yang menyatakan bahwa salah satu karakteristik kesantunan ialah kontekstualitas, di mana suatu hal bisa dipandang sopan santun pada suatu masyarakat namun belum tentu dipandang sama oleh masyarakat yang lain. Meski pun penggunaan pronomina antum sebenarnya menyalahi kaidah tata bahasa dalam bahasa Arab, faktor sosial dan budaya (Chaer, 2014: 310 - 311) terbukti mempunyai pengaruh terhadap perubahan makna dan penggunaannya. Dalam masyarakat Kalimantan Selatan, khususnya suku Banjar, kata ganti pian yang memiliki arti kamu dipandang lebih sopan untuk dipakai jika dibandingkan dengan kata ganti ikam meski keduanya memiliki arti yang sama. Hal inilah yang kemudian memengaruhi penggunaan pronomina antum dan menjadi sebuah kesepakatan arbitrer secara tidak langsung.

Pada kaitannya dengan prinsip kesantunan yang dikemukakan oleh Leech (2014: 35), santriwati memandang bahwa penggunaan pronomina antum sebagai salah satu cara menunjukkan rasa hormat kepada mitra tutur yang lebih tua atau disegani. Dengan kata lain, ketika santriwati menggunakan kata ganti antum untuk menyapa kakak kelas atau ustaz/ustazah mereka yang sebenarnya terjadi adalah pematuhan prinsip kesopanan penerimaan yang mengutamakan kemaksimalan rasa hormat terhadap orang lain (mitra tutur). Bagi santriwati, 


MIMESIS
VOL. 2. No. 1, Januari 2021
Universitas
Ahmad Dahlan

penggunaan dhomir anta/anti dalam berkomunikasi dengan orang yang lebih tua atau disegani dinilai kurang sopan.

\section{KESIMPULAN}

Dari penelitian ini dapat disimpulkan bahwa meski pronomina antum mengalami perubahan bahkan perluasan makna, penggunaannya pada santriwati di Pondok Modern AnNajah Cindai Alus Putri adalah representasi dari prinsip kesantunan yang sudah dibahas oleh banyak ahli. Pronomina antum dalam keseharian santriwati digunakan sebagai kata ganti yang mengacu pada kata ganti orang kedua laki-laki jamak, kata ganti sapaan terhadap orang yang lebih tua, dan kata ganti sapaan terhadap orang yang dihormati atau disegani. Sikap sosial dan budaya masyarakat Kalimantan Selatan memiliki andil yang besar dalam fenomena ini, di mana pronomina antum dipandang sebagai kata sapaan yang lebih halus dibanding pronomina anta atau anti yang biasa ditujukan bagi orang kedua tunggal baik laki-laki atau perempuan.

\section{DAFTAR PUSTAKA}

Al-Atsary, A. H. (2007). Pengantar Mudah Belajar Bahasa Arab. Bandung: Pustaka Adhwa. Al-Jarim, A., \& Amin, M. (2005). 'Ilmu An-Nahwi. Ponorogo: Darussalam .

Chaer, A. (2014). Linguistik Umum. Jakarta: PT Rineka Cipta.

Leech, G. N. (2014). The Pragmatics of Politeness. New York: Oxford University Press.

Meyer, c. F. (2009). Introducing English Linguistics. New York: Cambridge University Press. Muslich, M. (2007, April 26). KESANTUNAN BERBAHASA: SEBUAH KAJIAN SOSIOLINGUISTIK. Diambil kembali dari Masnur Muslich: Kiprah dan Idealismenya: http://muslich-m.blogspot.com/2007/04/kesantunan-berbahasa-sebuah-kajian.html

Rahadini, A. A. (2020). Pasemon: Wujud Keeleganan Tuturan Direktif Masyarakat Jawa. Jurnal Mimesis, 25-32.

Razin, A., \& Razin, U. (2015). Ilmu Nahwu untuk Pemula. Tim BISA.

Rusbiyantoro, W. (2014). KESANTUNAN MELALUI PEMILIHAN KATA SAPAAN DALAM BAHASA MELAYU KUTAI: Suatu Kajian Sosiopragmatik. SEMINAR NASIONAL PRASASTI (Pragmatik: Sastra dan Linguistik) (hal. 275-283). Prosiding Prasasti .

Sartono. (t.thn.). Bahasa Internasional. Diambil kembali dari Badan Pengembangan dan Pembinaan Bahasa Kementerian Pendidikan dan Kebudayaan: http://badanbahasa.kemdikbud.go.id/lamanbahasa/artikel/3100/bahasa-internasional Wardaugh, R., \& Fuller, J. M. (2015). An Introduction to Sociolinguistics. Wiley Blackwell 